\title{
課題に対する回答の確信度が随意筋収縮前後の表面筋電位変化に及ほす影響
}

\author{
○高橋 雄三（広島市立大学大学院情報科学研究科）
}

\section{Effects of cognitive confidence on EMG signal shifting during voluntary muscle contraction}

\section{Yuzo TAKAHASHI (Graduate School of Information Sciences, Hiroshima City University)}

\section{1.はじめに}

力，巧緻性，持続力をアシストする装置におい て，装着者の意図の推定はシステムの根幹をなす 重要な機能である.人間の意図は脳において生成 されるが，装置の操作という単純な動作の場合， 脳における意眓情報は複雑であり，装置に対する コマンド成分の抽出は，抽出アルゴリズムの複雑 さだけでなく，使用者に認知的な訓練を必要とす る.そこで，意図の最終形である動作の直近で意 図に関する命令を抽出し，人間の潜時の間にシス テムが動作できれば，生体から得られるコマンド は単純な動作命令のみで済むと考えられる。

著者はパワーアシスト装置の動作スイッチとし て筋電位信号を利用したシステムの開発を行って いる ${ }^{1)}$. しかし, 顕著な筋電位変化には随意成分 と不随意成分の両方が存在するが，筋電位成分か ら随意筋収縮とそれ以外とを区別することは難し い，そこで本研究では，学習が容易な刺激に対す る上腕二頭筋の随意筋収縮と学習が困難な刺激に 対する随意筋収縮を測定し，単純筋電位変化の中 に含まれる随意笳収縮にともなう特徴量について 実験的に検討することを目的とする.

\section{2. 方法}

\section{1 被験者}

被験者は両腕部の動作に支障ない健康な大学 生・大学院生 8 名（男女各 4名）とした。実験室 入室後，被験者には実験開始前に実験概要を十分 説明し，書面でインフォームドコンセントを書面 で確立した上で実験を開始した。

\section{2 . 2 装置}

被験者に提示する刺激 (矢印) は19 inch画面 (FlexScan S1901-B， iiyama) 上に提示した。視 覚刺激の提示と同時に $1 \mathrm{~V}$ の矩形波をDA変換器 CSI-360112 (Interface) を用いて出力した.上 腕二頭筋の筋電位は生体電極 SX-230-1000
(Biometrics) に接続したEMG アンプ (PTS-137, DKH 並びにK800, Biometrics）を用いて増幅し, 刺激トリガと同期させて TRIAS System (DKH) を 用いてサンプリング間隔 $1 \mathrm{~ms}$ で測定した。

\section{2 . 3 実験課題}

実験では，共有画面上に矢印を提示し，挙上す ベき腕をできるだけ速く挙上するよう被験者に求 めた，顕著な筋電位信号を計測するため，被験者 には両腕に250 gのダンベルを持たせた。刺激に 対する反応を強化するため, 刺激に対する反応 (右腕挙上 or 左腕を挙上) を十分に強化する学 習ステージと，学習ステージで獲得した反応から， 各被験者の判断で挙上する腕を決めて反応させる 実験ステージの 2 系の実験を行わせた。

（1）学習ステージ : 本ステージでは 3 段階の 刺激提示を行った。第 1 段階では画面に $[\rightarrow]$ が 提示されたら右腕を， $[\longleftarrow]$ が提示されたら左腕 を挙上させた。第 2 段階では画面に［个］が提示

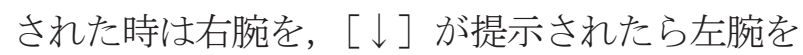
挙上させた。第 3 段階では前二段階での学習内容 を応用し，右上（第 1 象限）に矢印が提示された ら右腕を，左下 (第 3 象限) に矢印が提示された ら左腕を挙上させた。全ての被験者が同じ順序で 学習ステージを進み, 各段階での各腕の挙上回数 は40回（左右各20回）行わせた。各段階での矢印 の提示系列は被験者毎ランダムとした。

（2）実験ステージ: 本ステージでは画面上に左 上 (第 2 象限) または右下 (第 4 象限) に矢印を 提示した。実験ステージでは挙上すべき腕を教示 せず，被験者が自分の判断で挙げるべき腕を挙上 させた。また，刺激の強度（矢羽の網膜状の大き さ）の影響を検討するため，学習ステージで用い た刺激の矢羽の長さと同じ刺激（1倍）と長さ 2 倍，長さ 3 倍の矢羽を提示した。実験は刺激強度 ごとに実施し，各実験での繰り返し回数はでの80 回（各方向40回）とした。各刺激強度の実験順序， と提示方向の提示系列は被験者毎ランダムとした. 


\section{4 解析}

被験者が挙上すべき腕を決定し，動作が開始す る前におこる主導筋の伸長反射2)が起こった推定 される時刻（挙上動作準備開始時刻）を試行ごと に求めた。 具体的には，矢印が提示されてから50 $\mathrm{ms}$ 毎128 点の筋電位データに対してFFT 処理を 施し， $50 \mathrm{~ms}$ 毎の中心周波数を求めた. 前の区間 の中心周波数と現区間の中心周波数との差が閾值 $7.9 \mathrm{~Hz}^{3)}$ を超えた最初の時刻を挙上動作準備開始 時刻と定義した。挙上動作開始時刻は，2,550 ms の区間の筋電図を整流した後に累積加算波形を導 出し, $50 \mathrm{~ms}$ 毎の差分值を求めた. 前の区間の差 分值と現区間の差分值が2.0倍を超えた時刻の最 小值を挙上動作開始時刻と定義した.

\section{3. 結果}

図 1 には学習ステージでは矢印の提示方向ごと, 実験ステージでは刺激の強度（矢羽の長さ）ごと にみた挙上動作淮備時の中心周波数の増加量を示 す．学習ステージでは学習の難易度が高くなるに 従って中心周波数は増加する傾向が観察された. また，実験ステージでは刺激の強度が増すに従っ て中心周波数は増加する傾向が観察された.

図 2 には学習ステージでは矢印の提示方向ごと, 実験ステージでは刺激の強度（矢羽の長さ）ごと にみた挙上動作開始時刻を示寸。学習ステージで は矢印の方向が左右の時に挙上動作開始時刻が早 くなる傾向が観察された。一方, 実験ステージで は，刺激の強度に起因する顕著な挙上動作開始時 刻の変化は観察されなかった。

図 3 には学習ステージでは矢印の提示方向ごと にみた挙上腕の正答率，実験ステージでは刺激の 強度（矢羽の長さ）ごとにみた 2 名の被験者の挙 上腕の一致率を示す．学習ステージでは正答率は 98\%以上であったのに対し，実験ステージでは一 致率は75\%程度にまで低下していた。

\section{4.まとめ}

本研究で設定した刺激の内，学習が容易で挙上

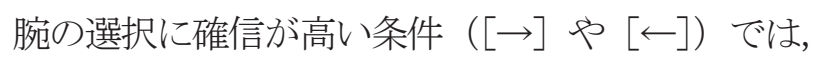
正答率が高く, 挙上動作開始時刻が早くなり, 挙 上動作準備時の上腕二頭筋の中心周波数も低くな る可能性が示唆された。 また, 刺激の強度が増 加すると中心周波数は高い周波数にシフトする可 能性も示唆された.

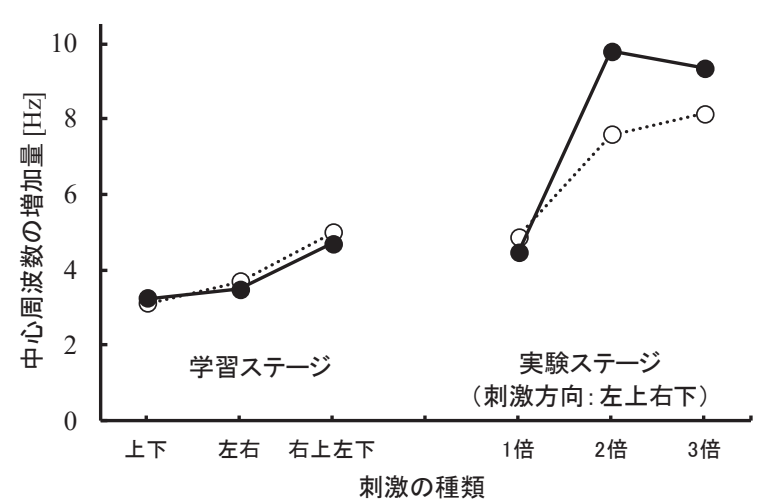

図 1 挙上動作準備時の中心周波数の増加量

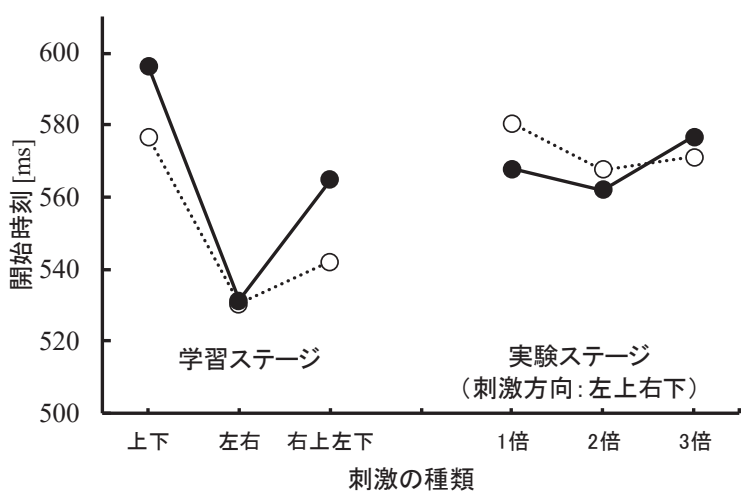

図 2 挙上動作開始時刻

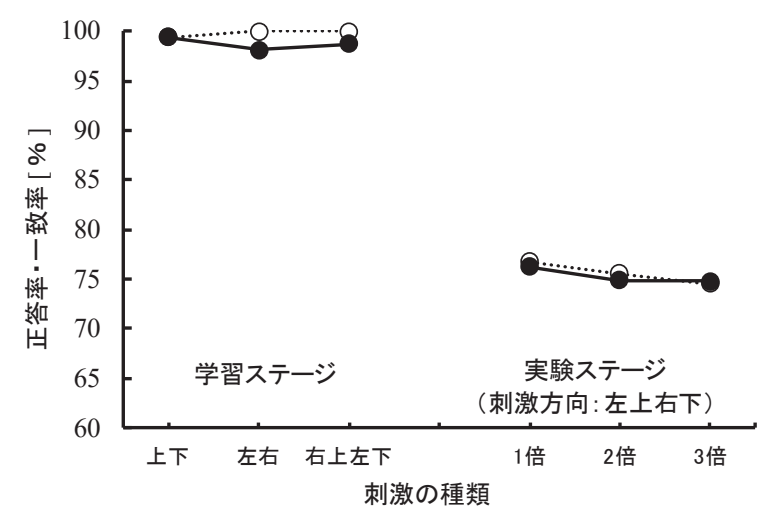

図 3 正答率・一致率

\section{参考文献}

1）北居潤，小岦貴弘，厚海慶太，高橋雄三，小作 敏晴 : “空気圧式パワーアシストのための筋電 位による人の動作予測システム” 日本機械学 会 中国四国支部第53 期総会-講演会CD-ROM 論 文集，2pages，2015.

2）高橋憲一，福田修，飯坂英雄，鈴木重男：“運 動準備状態における伸張反射の修飾：入出力 機構について 北海道大学医療技術短期大学部 紀要, 1, pp. 45-59, 1988.

3）高橋雄三 : 課題に対する回答の確信度が回答時 の随意筋収縮に及ぼす影響, 信学技報（電子情 報通信学会 福祉情報工学研究会） vol. 115, No. 269, pp. 33-35, 2015. 